\title{
IMPLEMENTASI PENDEKATAN SAINTIFIK DALAM PEMBELAJARAN TEMATIK DI KELAS VI SDN 033 ASMI KOTA BANDUNG
}

\author{
Siti Sholiha Nurfaidah ${ }^{1}$, Azis Lukman Praja ${ }^{2}$, Nurul Fazriyah ${ }^{3}$, Akhmad Mamad ${ }^{4}$ \\ ${ }^{123}$ Prodi Pendidikan Guru Sekolah Dasar FKIP Universitas Pasundan \\ ${ }^{4}$ SDN 033 Asmi Kota Bandung \\ 1sitinurfanurfaidah@unpas.ac.id, 2azislukmanpraja@unpas.ac.id, \\ 3nurulfazriyah@unpas.ac.id, ${ }^{4}$ akhmadasmi@gmail.com
}

\begin{abstract}
Changes in the context of education are always made in order to improve the quality of education output. One learning model that can be applied is thematic learning with a scientific approach. A scientific approach is a learning process that uses a scientific thought process. Where learning is very important for students to find and build their own knowledge that is fun and meaningful. The purpose of this research is to get a picture of the implementation of a scientific approach in thematic learning in class VI SDN 033 Asmi Bandung. This research is a descriptive research. The research subjects in this study were model teachers (lecturers who teach in schools) and class VI A students at SDN 033 Asmi. Data collection tools in this study are interview guidelines, observation sheets and study documentation. Data analysis was performed by data reduction, data display and conclusion drawing. The results showed that the model teacher had implemented learning using a scientific approach which was carried out through the steps of the activity: 1) observing, 2) asking questions, 3) trying, 4) associating, and 5) communicating. Each step has been implemented well but not always done sequentially on every learning that is done. Thematic learning with a scientific approach has made the learning process more active and enjoyable. So that students really become the center of activity in the learning process that takes place.
\end{abstract}

Keywords: thematic learning, scientific approach, curicullum of 2013

\begin{abstract}
ABSTRAK
Perubahan dalam konteks pendidikan senantiasa dilakukan dalam rangka meningkatkan kualitas dan mutu output pendidikan. Salah satu model pembelajaran yang dapat diterapkan ialah pembelajaran tematik dengan pendekatan saintifik. Pendekatan saintifik atau ilmiah merupakan proses pembelajaran yang menggunakan proses berpikir ilmiah. Dimana pembelajaran ini sangat penting bagi peserta didik untuk menemukan dan membangun pengetahuan mereka sendiri yang menyenangkan dan bermakna. Adapun tujuan dari penelitian ini ialah untuk mendapatkan gambaran pelaksanaan pendekatan saintifik dalam pembelajaran tematik di kelas VI SDN 033 Asmi Kota Bandung. Penelitian ini merupakan penelitian deskriptif. Subjek penelitian dalam penelitian ini adalah guru model (dosen yang mengajar di sekolah) dan siswa kelas VI A di SDN 033 Asmi. Alat pengumpul data dalam penelitian ini adalah pedoman wawancara, lembar observasi dan studi dokumentasi. Analisis data dilakukan dengan reduksi data, display data dan penarikan kesimpulan. Hasil penelitian menunjukkan bahwa guru model telah melaksanakan pembelajaran menggunakan pendekatan saintifik yang
\end{abstract}


dilakukan melalui langkah-langkah kegiatan: 1) mengamati, 2) menanya, 3) mencoba, 4) mengasosiasi, dan 5) mengkomunikasikan. Setiap langkah telah dilaksanakan dengan baik namun tidak senantiasa dilakukan secara berurutan pada setiap pembelajaran yang dilakukan. Pembelajaran tematik dengan pendekatan saintifik ini telah menjadikan proses pembelajaran lebih aktif dan menyenangkan. Sehingga peserta didik betul-betul menjadi pusat aktivitas dalam proses pembelajaran yang berlangsung.

Kata Kunci: pembelajaran tematik, pendekatan saintifik, kurikulum 2013

\section{A. Pendahuluan}

Pengembangan potensi peserta didik merupakan tujuan utama dari pendidikan. Hal ini tertuang dalam Undang-Undang Nomor 20 tahun 2003 tentang Sistem Pendidikan Nasional, Pasal 3, dimana peserta didik dibentuk agar menjadi manusia yang beriman dan bertakwa kepada Tuhan Yang Maha Esa, berakhlak mulia, sehat, berilmu, cakap, kreatif, mandiri, dan menjadi warga negara yang demokratis serta bertanggung jawab. Implikasi dari Undang-undang tersebut menuntut pelaksanaan pendidikan yang menjamin pada mutu pengembangan seluruh potensi peserta didik. Oleh karena itu, kurikulum yang diberlakukan harus senantiasa mendukung tujuan pendidikan nasional yang telah ditetapkan dalam Sisdiknas.

Kurikulum yang berlaku saat ini merupakan Kurikulum 2013 yang senantiasa dikembangkan, agar mampu dianggap sebagai kurikulum yang sesuai dalam menghadapi perubahan fakta dan realita kehidupan masyarakat serta isu-isu tantangan zaman. Bahkan Sufairoh (2016) menyatakan bahwa kurikulum 2013 bertujuan untuk mempersiapkan manusia Indonesia agar memiliki kemampuan hidup sebagai pribadi dan warga negara beriman, produktif, kreatif, inovatif, dan afektif serta mampu berkontribusi pada kehidupan bermasyarakat, berbangsa, bernegara dan peradaban dunia. Oleh karena itu, kurikulum 2013 dapat dikatakan sejalan atau mendukung ketercapaian pendidikan Nasional.

Pembelajaran kurikulum 2013 di Sekolah Dasar sangat dominan dengan pembelajaran tematik terpadu. Kemendikbud (2013) menyatakan bahwa pembelajaran tematik terpadu adalah pembelajaran dengan memadukan beberapa mata pelajaran melalui penggunaan tema, dimana peserta didik tidak mempelajari materi mata pelajaran 
secara terpisah, semua mata pelajaran yang ada di sekolah dasar sudah melebur menjadi satu kegiatan pembelajaran yang diikat dengan tema. Prastowo (2013) pembelajaran tematik terpadu merupakan pendekatan pembelajaran yang mengintegrasikan berbagai kompetensi dari berbagai mata pelajaran ke dalam berbagai tema.

Pembelajaran tematik terpadu ini menuntut keterlibatan dan aktivitas siswa yang lebih banyak. Guru hanya berperan sebagai fasilitator yang membantu mengembangkan potensi siswa melalui penugasan dan seluruh proses pembelajaran yang berlangsung. Adapun model pembelajaran tematik terpadu ini dilaksanakan melalui pendekatan ilmiah atau pendekatan saintifik (scientific approach). Pendekatan saintifik ini merupakan pembelajaran menggunakan proses berpikir ilmiah yang mencakup komponen: mengamati, menanya, mencoba, mengolah, menyajikan, menyimpulkan dan mencipta. Bahkan Mastura (2017) menyatakan bahwa pendekatan ilmiah ini dapat dijadikan sebagai jembatan untuk perkembangan sikap, keterampilan dan pengetahuan peserta didik.
Marzuki (2015) menjelaskan bahwa melalui pendekatan saintifik peserta didik akan dituntut untuk membangun pengalaman yang lebih baik. Bahkan Hosnan (2014) mengungkapkan bahwa pendekatan saintifik bertujuan untuk meningkatkan kemampuan intelektual, khususnya kemampuan berpikir tingkat tinggi (high order thinking), (2) membentuk kemampuan peserta didik dalam menyelesaikan permasalahan secara sistematik, (3) menbentuk kondisi bahwa belajar merupakan suatu kebutuhan yang dirasakan peserta didik, meningkatkan hasil belajar,

melatih kemampuan komunikasi peserta didik, dan mengembangkan karakter peserta didik.

Keberhasilan pembelajaran model tematik integratif dengan pendekatan saintifik tentu harus ditunjang dengan berbagai aspek, salah satunya kemampuan guru dalam mengelola pembelajaran dan penentuan metode yang digunakan, serta proses pengelolaan pembelajaran tersebut harus diarahkan hingga menjadi suatu proses bermakna dan kondusif. Sedangkan hasil observasi 
Didaktik : Jurnal IImiah PGSD STKIP Subang, ISSN Cetak : 2477-5673 ISSN Online : 2614-722X Volume V Nomor 2, Desember 2019

pendahuluan yang dilakukan peneliti, proses pembelajaran yang berlangsung di SDN 033 ASMI masih belum sepenuhnya menerapkan kelima komponen pendekatan saintifik seperti disampaikan oleh Kemendikbud, serta belum secara konsisten melangsungkan pembelajaran tematik terpadu kurikulum 2013. Pembelajaran yang berlangsung cenderung bersifat teoritis, dimana guru masih mendominasi proses pembelajaran sebagai penyampai informasi atau transmitor pengetahuan.

Oleh karena itu, implementasi pendekatan saintifik dalam pembelajaran tematik di kelas VI SDN 033 Asmi Kota Bandung perlu dilakukan sekaligus diteliti untuk mengungkap hal-hal apa saja yang dapat digambarkan melalui implementasi pembelajaran tersebut. Agar kualitas pembelajaran yang lebih baik dapat tercapai sebagaimana telah dipaparkan dalam latar belakang di atas. Sehingga pembelajaran dengan pendekatan tersebut dapat diterapkan secara konsisten.

\section{B. Metode Penelitian}

Penelitian ini merupakan penelitian deskriptif dan menggunaan pendekatan kualitatif. Subjek penelitian dalam penelitian ini adalah guru model (dosen yang mengajar di sekolah) dan siswa kelas VI A di SDN 033 Asmi Kota Bandung.

Alat pengumpul data dalam penelitian ini adalah pedoman wawancara, lembar observasi dan studi dokumentasi mengenai implementasi teori dan praktik pembelajaran tematik menggunakan pendekatan saintifik.

Analisis data dilakukan dengan reduksi data, display data dan penarikan kesimpulan. Pengecekan keabsahan data dilakukan menggunakan teknik triangulasi sumber.

\section{C.Hasil Penelitian dan Pembahasan}

Diberlakukannya kurikulum 2013 menuntut banyak perubahan dalam ruang lingkup pendidikan. Pembelajaran tematik menggunakan pendekatan saintifik pun menjadi model yang harus diterapakan menyesuaikan perubahan kurikulum tersebut.

Pembelajaran dengan menggunakan pendekatan saintifik diharapkan dapat memberikan 
Didaktik : Jurnal IImiah PGSD STKIP Subang, ISSN Cetak : 2477-5673 ISSN Online : 2614-722X Volume V Nomor 2, Desember 2019

pengalaman secara langsung kepada peserta didik. Hal ini sejalan dengan Agus Sujarwanta (2012) yang menyatakan bahwa pembelajaran dengan pendekatan ini menekankan pada pemberian pengalaman secara langsung baik menggunakan observasi, eksperimen maupun cara yang lainnya, sehingga realitas yang informasi atau data yang diperoleh selain valid juga dapat dipertanggungjawabkan.

Pembelajaran menggunakan pendekatan ini penting untuk dilaksanakan. Namun, mengingat hasil pengamatan sebelumnya menunjukkan bahwa pembelajaran yang berlangsung di kelas VI SDN 033 Asmi masih belum seutuhnya menerapkan pembelajaran tematik dengan pendekatan saintifik. Maka dari itu, kami (dosen model dengan guru kelas) melakukan kolaborasi untuk melaksanakan pembelajaran yang diharapkan. Bentuk kolaborasi yang dilaksanakan berupa kolaborasi dalam perancangan perangkat pembelajaran maupun dalam pelaksanaan pembelajaran.

Perancangan

perangkat pembelajaran yang dimaksud tidak hanya sekadar RPP saja, melaikan juga LKPD (lembar kerja peserta didik), sumber dan media yang akan digunakan dan lembar penilaian peserta didik. Karena itu, penyusunan perangkat pembelajaran kolaboratif ini sudah dipersiapkan sebelum pembelajaran dimulai. Hal ini dilakukan agar guru kelas maupun dosen dapat saling memberikan kontribusi langsung terhadap pembelajaran yang diinginkan dengan capaian yang maksimal. Berikut foto kegatan tersebut.

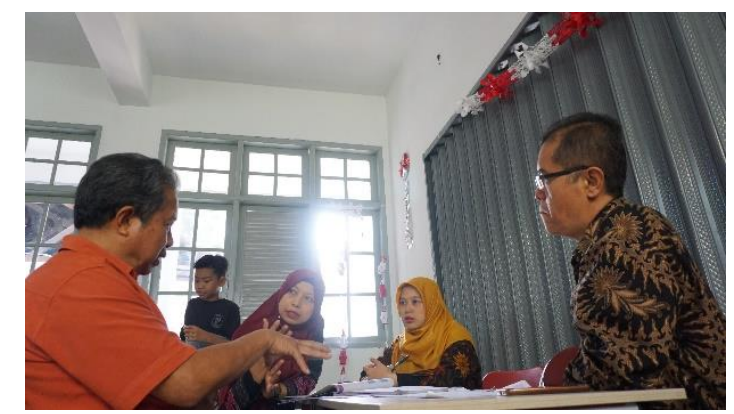

Gambar 1. Perancangan perangkat pembelajaran kolaboratif

Sedangkan pelaksanaan pembelajaran kolaboratif yang dimaksud adalah dosen berperan sebagai guru model dan guru kelas berperan sebagai observer yang juga dibantu oleh guru kelas dan dosen yang lain sebagai penyeimbang data dalam observassi. Hal ini dilakukan dengan maksud pembelajaran yang berlangsung akan senantiasa mendapatkan masukan yang konstruktif untuk pembelajaran yang 
Didaktik : Jurnal IImiah PGSD STKIP Subang, ISSN Cetak : 2477-5673 ISSN Online : 2614-722X Volume V Nomor 2, Desember 2019

lebih baik di kemudian hari. Berikut foto kegiatan tersebut:

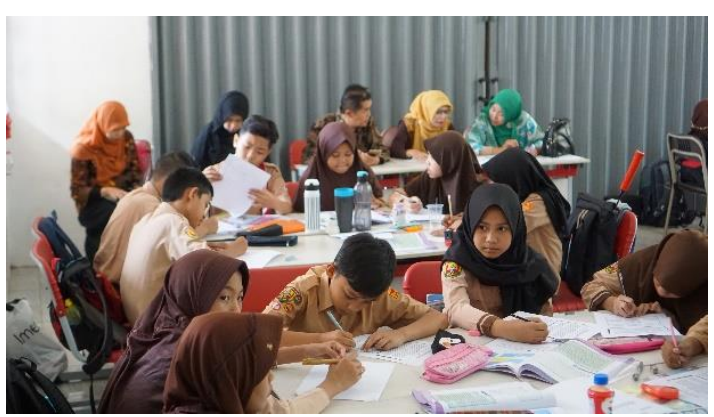

Gambar 2. Proses pembelajaran diamati oleh observer

Adapun gambaran pelaksanaan pembelajaran tematik menggunakan pendekatan saintifik yang lebih menyeluruh akan ditinjau berdasarkan rancangan pelaksanaan pembelajaran dan implementasi pembelajaran sebagai berikut.

\section{Rancangan Pembelajaran}

Guru telah menjabarkan langkah-langkah pembelajaran menggunakan pendekatan saintifik dalam menyusun rancangan pelaksanaan pembelajaran (RPP) tematik pada setiap pembelajaran, yaitu dengan mencantumkan langkah kegiatan pembelajaran meliputi $5 \mathrm{M}$ (mengamati, menanya, mencoba, mengasosiasi, dan mengkomunikasikan). Adapun pencantuman komponen $5 \mathrm{M}$ tersebut memungkinkan dicantumkan secara berurutan maupun tidak. Mengingat urutan materi dan langkah pembelajaran yang harus tetap sinkron di dalam sebuah tema pembelajaran.

Hal ini tidak salah, sebagaimana Sani (2013) mengatakan bahwa pendekatan saintifik dapat dilakukan melalui prosedur yang luwes, yaitu dapat disesuaikan dengan pengetahuan yang hendak dipelajari. Pada suatu pembelajaran mungkin anak dituntut untuk mengamati terlebih dahulu, baru dilanjutkan dengan memunculkan sejumlah pertanyaan. Namun, pada pembelajaran lainnya mungkin peserta didik harus mengajukan pertanyaan lebih dahulu dan kemudian disusul dengan kegiatan mengamati dan mencoba.

\section{Implementasi Pembelajaran}

Pelaksanaan pembelajaran tematik menggunakan pendekatan saintifik yang dilaksanakan oleh guru model (dosen yang mengajar di sekolah) di SDN 033 Asmi Kota Bandung terdiri dari tiga kegiatan sebagaimana dilaksanakan dalam pembelajaran konvensional, yakni: kegiatan pendahuluan/apersepsi, kegiatan inti, dan kegiatan penutup. 
Kegiatan pendahuluan dilakukan dengan menanyikan lagu bersama, menayangkan slide atau video, bahkan membawa benda-benda atau media yang menarik ke dalam kelas yang sesuai dengan subtema pada hari pembelajaran berlangsung. Selain itu, di dalam kegiatan pendahuluan guru terbiasa untuk mendiskusikan kompetensi yang sudah dipelajari; serta menjelaskan tujuan pembelajaran yang hendak dicapai pada pembelajaran yang berlangsung. Hasil temuan berdasar studi dokumentasi dan pengamatan menunjukkan bahwa sebagian besar kegiatan-kegiatan tersebut telah dilaksanakan di setiap pembelajaran dan telah dicantumkan di dalam RPP.

Namun, tidak dapat dipastikan bahwa ketika seluruh kegiatan telah tercatum di dalam RPP, maka membuka pembelajaran dapat berlangsung dengan mudah. Guru perlu memiliki keterampilan membuka pelajaran yang dapat menarik perhatian peserta didik dengan memperhatikan situasi dan kondisi yang sedang berlangsung. Apalagi guru yang mengajar saat itu merupakan guru model yang bukan guru kelas dimana kemungkinan lebih mendapat kemudahan karena telah mengenal peserta didik lebih dalam. Namun sejauh pengamatan yang telah dilakukan, guru model telah mampu mengambil perhatian siswa di awal kegiatan pembelajaran, sehingga kegiatan selanjutnya berlangsung secara kondusif. Hal ini mungkin sejalan dengan pernyataan Uno (2013) apabila guru dapat melakukan kegiatan pendahuluan dengan menarik, maka akan dapat meningkatkan motivasi belajar peserta didik. Sehingga dapat dikatakan, bahwa kegiatan awal ini tidak bisa dipandang sebelah mata, karena kegiatan ini akan menjadi penentu berlangsungnya kualitas kegiatan pembelajaran berikutnya.

Adapun

pembelajaran

kegiatan

inti menggambarakan dapat pendekatan saintifik yang dilaksanakan di kelas VI SDN 033 Asmi Kota Bandung secara rinci, yang akan dipaparkan dalam tiap komponen saintifik, sebagai berikut:

\section{a. Mengamati (Observing)}

Kegiatan mengamati dapat membantu melatih kesungguhan, ketelitian, kemampuan mencari informasi peserta didik melalui kegiatan membaca, mendengar, menyimak, melihat (tanpa atau 
Didaktik : Jurnal Ilmiah PGSD STKIP Subang, ISSN Cetak : 2477-5673 ISSN Online : 2614-722X Volume V Nomor 2, Desember 2019

dengan alat). Kegiatan mengamati adalah kegiatan yang menggunakan semua alat indera manusia (penglihatan, penciuman, pendengaran, pengecap, dan peraba) untuk mendapat suatu informasi atau data-data (Permendikbud Nomor 81 A, 2013).

Berdasarkan pada hasil pengamatan di lapangan, sebagian besar kegiatan pembelajaran, proses mengamati dilakukan sebagai langkah awal dalam pendekatan saintifik. Siswa diberikan kesempatan mengamati teks, benda, maupun fenomena sebagi bahan pencarian informasi. Kegiatan ini merupakan kegiatan yang memancing rasa ingin tahu siswa, menambah pengetahuan siswa, dan menjadi bahan diskusi dalam kelompok sehingga proses pembelajaran berlangsung secara aktif, sebagaimana terlihat pada dokumentasi berikut ini.

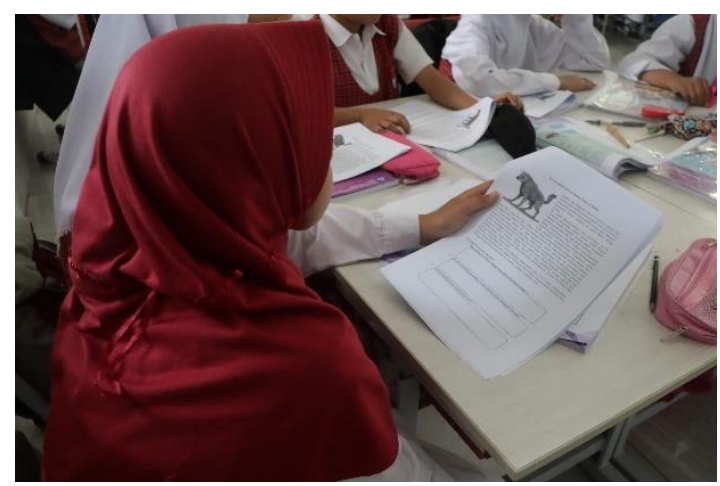

Gambar 3. Proses mengamati teks

\section{b. Menanya}

Dalam Permendikbud Nomor 81 A (2013) kegiatan 'menanya' dalam pembelajaran saintifik adalah mengajukan pertanyaan tentang informasi yang tidak dipahami dari apa yang diamati atau pertanyaan untuk mendapatkan informasi tambahan.

Berdasar pada temuan, kegiatan ini masih belum secara aktif dilakukan oleh setiap siswa, hanya beberapa orang yang cukup aktif dan memiliki rasa ingin tahu yang tinggi yang mengajukan pertanyaan sebagimana dimaksud. Namun kegiatan ini cukup menarik perhatian, karena pada proses ini penilaian terhadap siswa akan lebih mudah. Berikut gambaran yang didapatkan di lapangan.

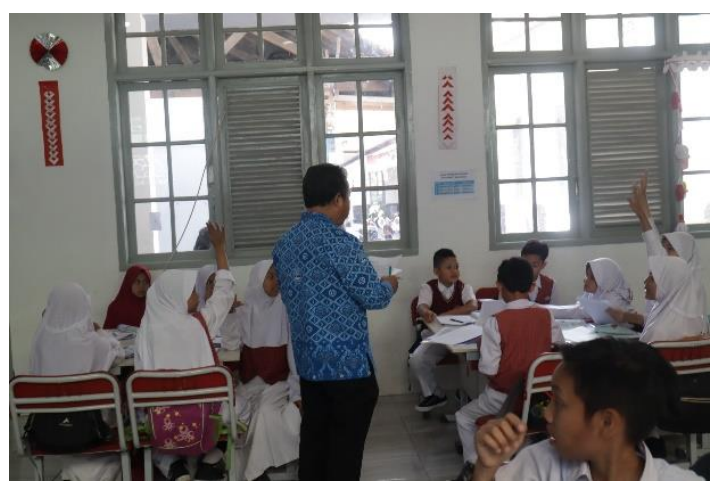

Gambar 4. Beberapa siswa aktif bertanya

\section{c. Mencoba}

Mencoba

(experimenting) dimaksudkan untuk mengembangkan berbagai ranah tujuan belajar, yaitu sikap, keterampilan, dan pengetahuan 
Didaktik : Jurnal Ilmiah PGSD STKIP Subang, ISSN Cetak : 2477-5673 ISSN Online : 2614-722X Volume V Nomor 2, Desember 2019

(Kemendikbud, 2013). Adapun pada pelaksanaan pembelajaran, aktifitas mencoba ini dilakukan dengan membuat sebuah naskah drama, mencatat fenomena dan hal-hal menarik dari sebuah teks, menganalisis dan menyajikan data dari hasil pengamatan yang telah dilakukan.

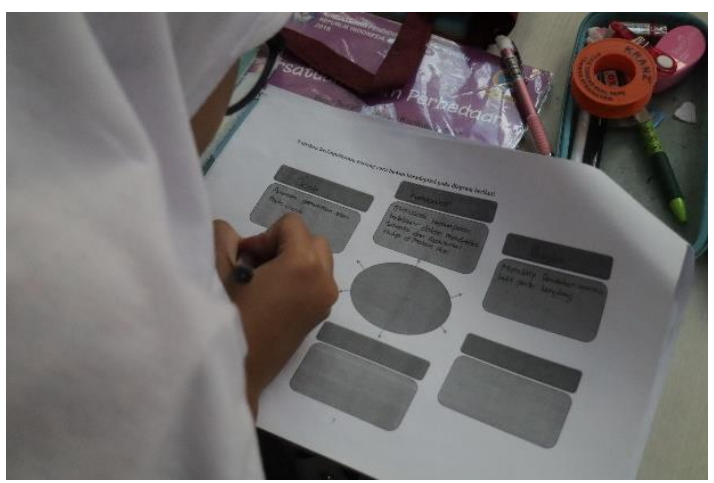

Gambar 5. Proses mencatat fenomena yang menarik

Dalam hal ini, siswa sangat berkontribusi secara aktif di dalam merespon setiap upaya experimen yang distimulasi oleh guru. Kegiatan ini cukup menyita waktu banyak dari langkah lainnya.

\section{d. Menalar/mengasosiasi}

Dalam Permendikbud Nomor 81 A (2013) kegiatan 'menalar' adalah memproses informasi yang sudah dikumpulkan baik terbatas dari hasil kegiatan eksperimen maupun hasil dari kegitan mengamati dan kegiatan mengumpulkan informasi.
Adapun dalam lapangan, kegiatan ini dilakukan dengan saling mengkonfirmasi ide bersama teman kelompoknya, seperti berikut ini.

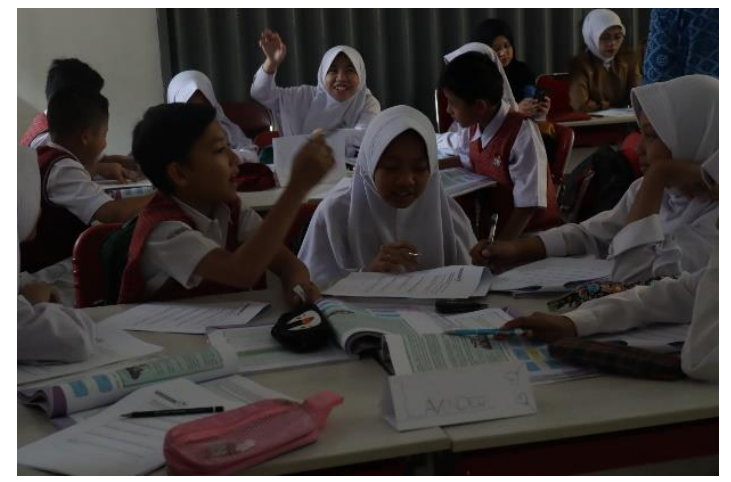

Gambar 6. Proses diskusi kelompok

Kompetensi yang diharapkan adalah mengembangkan sikap jujur, teliti, disiplin, taat aturan, kerja keras, kemampuan menerapkan prosedur dan kemampuan berpikir induktif serta deduktif dalam menyimpulkan.

\section{e. Mengkomunikasikan}

Keterampilan berkomunikasi sangat penting dimiliki oleh setiap orang, termasuk siswa. Menurut Samatowa (2006) hal ini berkaitan dengan proses penyampaian informasi atau data-data, baik secara tertulis maupun lisan. Kegiatan yang termasuk keterampilan berkomunikasi diantaranya menyajikan informasi baik lisan maupun tulisan, menyajikan data dan informasi dalam bentuk model, gambar, grafik, diagram, tabel, dan lain-lain. 
Didaktik : Jurnal IImiah PGSD STKIP Subang, ISSN Cetak : 2477-5673 ISSN Online : 2614-722X Volume V Nomor 2, Desember 2019

Adapun pelaksanaan kegiatan 'mengkomunikasikan' dilakukan melalui penyampaian secara lisan dan tulisan yang disajikan secara berkelompok dan diwakili oleh salah satu dari kelompoknya, seperti berikut ini.

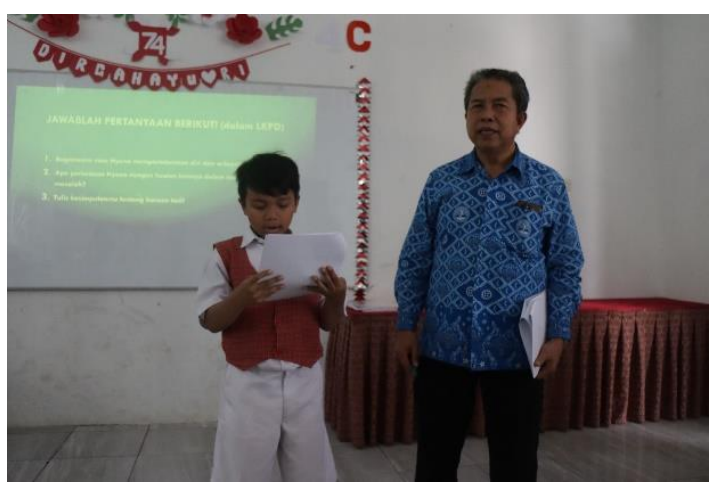

Gambar 7. Siswa mengkomunikasikan jawaban di depan kelas.

Kegiatan ini sangat menarik perhatian siswa dari kelompok lainnya untuk saling menyimak hasil dari proses pembelajaran yang telah dilakukan oleh setiap kelompok.

\section{Kesimpulan}

Pelaksanaan pembelajaran tematik dengan pendekatan saintifik telah terlaksana dengan baik. Hal ini ditunjukkan dari rancangan pelaksanaan pembelajaran dan implementasi pembelajaran yang telah diamati. Langkah-langkah pelaksanaan pendekatan saintifik meliputi kegiatan: 1) mengamati, 2) menanya, 3) mencoba, 4) mengasosiasi,

dan

mengkomunikasikan. Setiap langkah telah dilaksanakan dengan baik namun tidak senantiasa dilakukan secara berurutan pada setiap pembelajaran yang dilakukan. Pembelajaran tematik dengan pendekatan saintifik ini telah menjadikan proses pembelajaran lebih aktif dan menyenangkan. Sehingga peserta didik betul-betul menjadi pusat aktivitas dalam proses pembelajaran yang berlangsung.

\section{DAFTAR PUSTAKA}

Dedpiknas. (2003). Undang-undang Ri No. 20 Tahun 2003 Tentang Sistem Pendidikan Nasional. Jakarta

Hosnan, M. (2014). Pendekatan Saintifik dan Kontekstual dalam Pembelajaran Abad 21: Kunci Sukses Implementasi Kurikulum 2013. Jakarta: Ghalia Indonesia

Kemendikbud. (2013). Kerangka Dasar Kurikulum 2013. Jakarta Marzuki. (2015). Green School in Perspective Physically, Psychologically and Pedagogically of Implementing Thematic Learning in Primary School. Theme:"The Uniqueness of Educational Practices Towards Harmonization of the Asean Community in 2015". Proceeding The 2015 International Seminar on Education. Grage Horizon Hotel, Bengkulu, 16-18 
Januari 2015. FKIP Bengkulu University Press.

Mastura. (2017). Implementassi Saintifik dalam Pembelajaran Tematik di Sekolah Dasar Nanga Pinoh.

Prastowo, Andi. (2013).

Pengembangan Bahan Ajar Tematik- Panduan Lengkap. Aplikatif. Yogyakarta: DIVA P

Samatowa, Usman. (2006).

Bagaimana Membelajarkan IPA di Sekolah Dasar. Jakarta: Direktorat Pendidikan Nasional

Sani, Ridwan Abdullah. (2013). Pembelajaran Saintifik untuk Implementasi Kurikulum 2013. Jakarta: PT Bumi Aksara.

Sufairoh. (2016). "Pendekatan Saintifik \& Model Pembelajaran K13". Jurnal Pendidikan Profesional, Volume 5, No 3, Desember 2016.

Sujarwanta, Agus. (2012). "Mengkondisikan Pembelajaran IPA dengan Pendekatan Saintifik". Jurnal Nuansa Kependidikan Vol 16 Nomor 1, November 2012.

Uno, Hamzah \& Mohammad, Nurdin. (2013). Belajar dengan Pendekatan Pembelajaran AILKEM. Jakarta: Bumi Aksara. 